\title{
PEMBERDAYAAN YAYASAN DISABILITAS BHAKTI SENANG HATI DALAM MENINGKATKAN PENDAPATAN DI DESA SIANGAN GIANYAR
}

\author{
Ita Sylvia Azita Azis ${ }^{1}$, A.A.Bagus Amlayasa ${ }^{2}$,Dewa Ayu Putu Nitiwidari³, \\ Nengah Ganawati ${ }^{4}$ \\ 1,2,3,4 Fakultas Ekonomi dan Bisnis, Universitas Warmadewa \\ Email: amlayasaaabgs@gmail.com²
}

\begin{abstract}
Difabel or disability is a term that includes interference, activity limitations, and participation restrictions. A disorder is a problem with the body's function or structure; An activity limitation is a difficulty faced by an individual in carrying out a task or action, while a participation restriction is a problem experienced by an individual in involvement in life situations. So disability is a complex phenomenon, reflecting the interaction between the characteristics of a person's body and the characteristics of the society in which he or she lives. This community partnership program aims to increase partners' entrepreneurial motivation and provide skills in the use of internet media to support product marketing functions in the form of proactive marketing strategies in order to increase life independence. The methods used in this service are: lectures, question and answer discussions, and demonstration methods for online marketing training programs. The result of this activity is that participants in this case people with disabilities who are under the Bhakti Happy Hati Gianyar Foundation are very enthusiastic about listening to counseling related to literacy and motivation to increase the entrepreneurial spirit and understand using social media applications as online marketing as an effort to increase life independence.
\end{abstract}

Keywords: Persons with Disabilities, Entrepreneurial, Online Marketing

\begin{abstract}
Abstrak. Difabel atau disabilitas adalah istilah yang meliputi gangguan, keterbatasan aktivitas, dan pembatasan partisipasi. Gangguan adalah sebuah masalah pada fungsi tubuh atau strukturnya; suatu pembatasan kegiatan adalah kesulitan yang dihadapi oleh individu dalam melaksanakan tugas atau tindakan, sedangkan pembatasan partisipasi merupakan masalah yang dialami oleh individu dalam keterlibatan dalam situasi kehidupan. Jadi disabilitas adalah sebuah fenomena kompleks, yang mencerminkan interaksi antara ciri dari tubuh seseorang dan ciri dari masyarakat tempat dia tinggal. Program kemitraan masyarakat ini bertujuan untuk meningkatkan motivasi kewirausahaan mitra serta memberikan keterampilan dalam penggunaan media internet untuk menunjang fungsi pemasaran produk berupa strategi pemasaran yang proaktif agar dapat meningkaatkan kemandirian hidup. Metode yang digunakan dalam pengabdian ini adalah: ceramah, tanya jawab diskusi, dan metode demonstrasi untuk program pelatihan pemasaran online. Hasil kegiatan ini adalah peserta dalam hal ini penyandang disabilitas yang bernaung dibawah Yayasan Bhakti Senang Hati Gianyar sangat antusias mendengarkan penyuluhan berkaitan dengan literasi dan motivasi untuk meningkatkan jiwa kewirausahaan serta memahami menggunakan aplikasi media sosial sebagai pemasaran online sebagai upaya untuk meningkatkan kemandirian hidup.
\end{abstract}

Kata kunci : Penyandang Disabilitas, Kewirausahaan, Pemasaran Online

\section{PENDAHULUAN}

Penyandang disabilitas memiliki kedudukan, hak dan kewajiban yang sama dengan masyarakat non disabilitas. Sebagai bagian dari warga negara Indonesia, sudah sepantasnya penyandang disabilitas mendapatkan perlakuan khusus, yang dimaksudkan sebagai upaya perlindungan dari kerentanan terhadap berbagai tindakan diskriminasi dan terutama perlindungan dari berbagai pelanggaran hak asasi manusia. Menurut Undang - Undang Nomor 19 tahun 2011 menyatakan: "Setiap penyandang disabilitas harus bebas dari penyiksaan atau perlakuan yang kejam, tidak manusiawi, merendahkan martabat manusia, bebas dari eksploitasi, kekerasan dan perlakuan semena mena, serta memiliki hak untuk mendapatkan penghormatan atas integritas mental dan fisiknya berdasarkan kesamaan dengan orang lain. Termasuk didalamnya hak untuk mendapatkan perlindungan dan pelayanan sosial dalam rangka kemandirian, serta dalam keadaan darurat". Sementara, menurut Undang-Undang Republik Indonesia Nomor 8 Tahun 2016 Mengenai 
Penyandang Disabilitas dinyatakan bahwa: "Penyandang Disabilitas adalah setiap orang yang mengalami keterbatasan fisik, intelektual, mental, dan/atau sensorik dalam jangka waktu lama yang dalam berinteraksi dengan lingkungan dapat mengalami hambatan dan kesulitan untuk berpartisipasi secara penuh dan efektif dengan warga negara lainnya berdasarkan kesamaan hak".

Berdasarkan Undang - Undang tersebut penyandang disabilitas harus dijaga dan diperlakukan dengan baik karena mereka mengalami keterbatasan fisik, intelektual, mental, dan/atau sensorik dalam jangka waktu yang lama dalam berinteraksi dengan lingkungannya sehingga mengalami hambatan dan kesulitan untuk berpartisipasi secara penuh dan efektif dengan warga negara lainnya berdasarkan kesamaan hak. Untuk keberlanjutan dan masa depan para penyandang disabilitas ini diperlukan adanya suatu terobosan baru yang sering di kenal dengan kecakapan hidup. dan hal ini sangat dibutuhkan dan diperlukan bagi mereka. Kecakapan hidup sebagai inti dari kompetensi dan hasil pendidikan adalah kecakapan yang dimiliki seseorang untuk berani menghadapi problema hidup dan kehidupan dengan wajar tanpa merasa tertekan, kemudian secara proaktif dan kreatif mencari serta menemukan solusi sehingga akhirnya mampu mengatasinya (Suci,2020)
Kecakapan hidup sebagai bekal untuk menapaki kemandirian hidup ini sangat dibutuhkan di lingkungan masyarakat dengan kondisi yang minim lapangan kerja seperti di Negara kita saat ini. Hal tersebut diperparah dengan banyaknya calon tenaga kerja yang kurang terampil sehingga semakin mempersempit kesempatan untuk bekerja. Maka dibutuhkan suatu cara untuk menumbuhkan semangat kemandirian di lingkungan masyarakat yang masih produktif dengan konsep kewirausahaan. Dengan mengembangkan konsep kewirausahaan diharapkan akan dapat menunjang pemberdayaan masyarakat agar lebih produktif di berbagai bidang. (Hidayati dan Ningsih,2017)

Kemandirian hidup juga sangat dibutuhkan oleh Yayasan Bhakti Senang Hati di desa Siangan Gianyar yang selanjutnya disebut mitra dalam pengabdian ini. Beroperasi sejak 2003, Senang Hati memperoleh status Yayasan pada Desember 2014 dan merupakan satusatunya yayasan di Bali yang dimiliki dan dijalankan oleh para penyandang cacat. Upaya untuk membentuk mental wirausaha sebenarnya telah dilakukan oleh para pengurus Yayasan. Mereka pernah mendapatkan bantuan dari Dinas Sosial Kabupaen Gianyar berupa peralatan mesin jahit serta pelatihan keterampilan bagi anak asuh panti. Keterampilan memasak dan membuat kerajinan tangan dari batu-batuan juga pernah didapatkan oleh anak asuh.

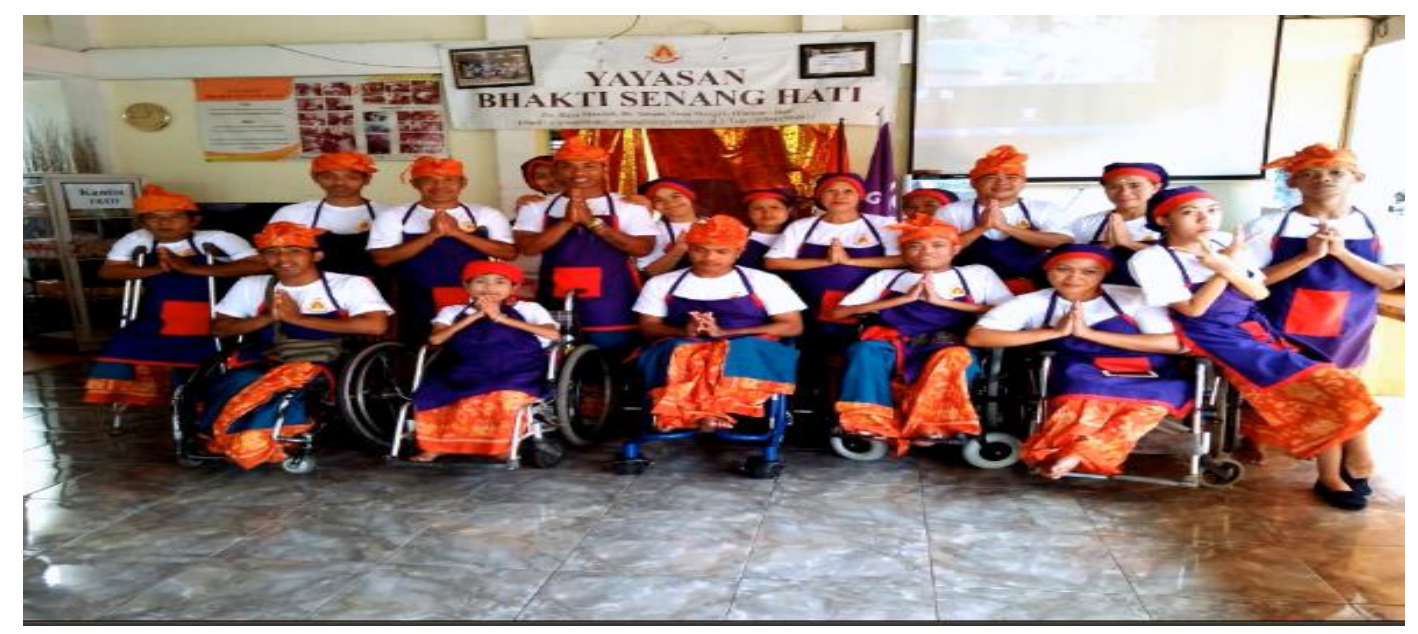

Gambar 1. Para Penyandang Disabilitas

Usaha kerajinan tangan mendapat perhatian khusus dari penyandang disabilitas. Hal ini dibuktikan dengan banyak beraneka ragam hasil kerajinan tangan yang berhasil diproduksi dan kemudian dipasarkan. Namun, karena kurangnya sentuhan softkill 
dan pemahaman membangun kemandirian dengan jiwa kewirausahaan, usaha tersebut menjadi tidak efektif. Selama ini, hasil kerajinan mereka hanya dipajang di gedung aula Yayasan sembari menunggu pembeli atau bahkan wisatawan yang berkunjung secara langsung.

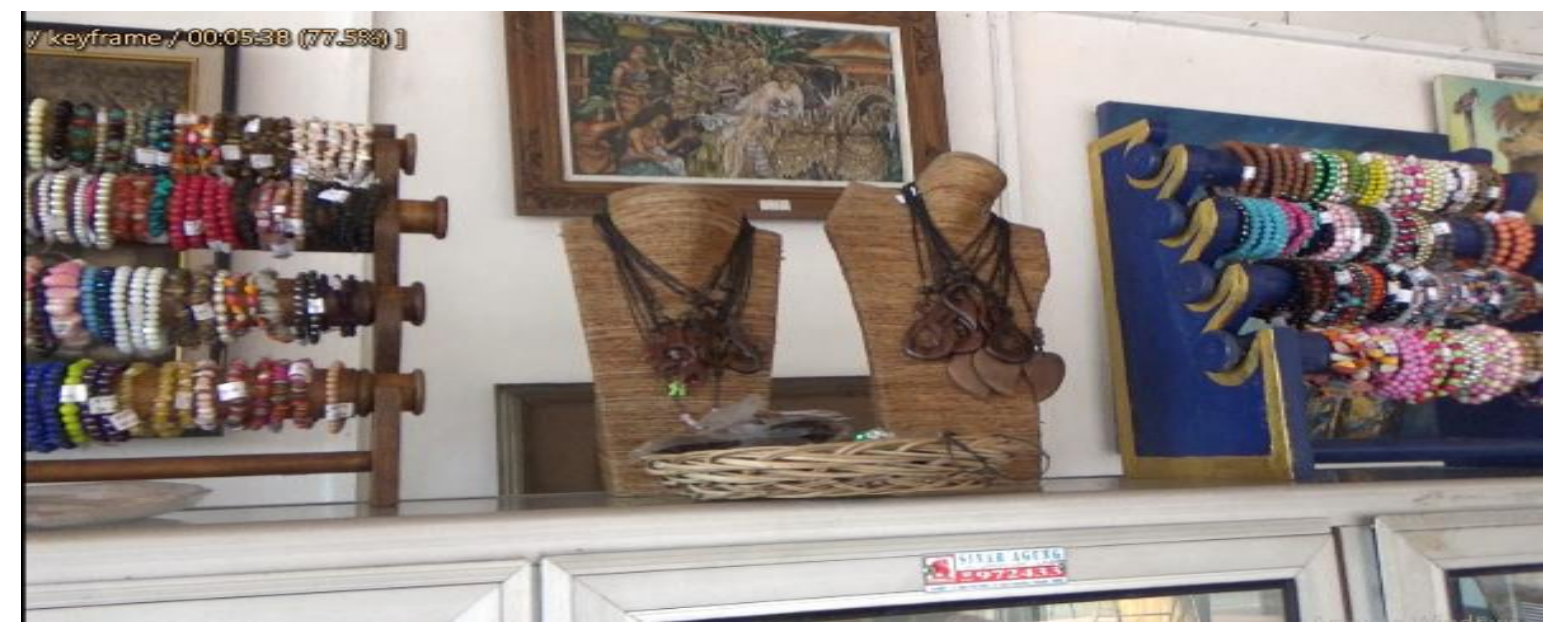

Gambar 2. Aneka Produk Kerajinan Tangan

Adanya pandemi covid1-19 di Indonesia, memberi tekanan kepada pola perubahan kehidupan masyarakat yang cukup signifikan, terutama di sektor perekonomian. Sebagian masyarakat Indonesia mengalami perubahan perilaku konsumen. Tak sedikit perusahaan di Indonesia yang mengalami penurunan penjualan. Pandemi ini juga berdampak besar unit usaha kerajinan mitra, serta berpengaruh besar terhadap kelangsungan usaha dan kemandirian mereka. Salah satu solusi untuk mengatasi terbatasnya ruang gerak pembeli ini adalah mau tidak mau mitra harus memanfatkan teknologi informasi dalam hal ini media sosial sebagai alat bantu untuk mengembangkan usaha melalui pemasaran online. Pentingnya pemanfaatan media sosial untuk kegiatan pemasaran diungkap oleh Pramuki dan Ayu (2020) yang menjelaskan bahwa teknologi informasi media sosial menjadi peranan penting bagi pelaku UMKM dalam memasarkan produk mereka di Kabupaten Badung-Bali. Hal senada juga dinyatakan oleh Achmad (2020) yang menyatakan bahwa pemanfaatan media sosial berbasis internet juga dapat membantu Usaha Kecil dan Menengah (UKM) untuk dapat bekerjasama dengan pengusaha lainnya. Sehingga dengan demikian hasil kegiatan pemasaran penjualan produk kerajinan mereka menjadi lebih informatif dan dikenal oleh masyarakat. Untuk has tersebut, peran inovasi pemasaran menjadi sangat penting untuk diterapan dan memotivasi mereka untuk menjadi lebih mandiri.

Berdasarkan hal tersebut kami Tim Pelaksana PKM Universitas Warmadewa turut hadir secara langsung memberikan pelatihan kepada mitra dalam hal penyuluhan sosial media sebagai bentuk strategi marketing bagi usaha kerajinan mitra. Dari analisa situasi yang telah dipaparkan sebelumnya, maka dirumuskan permasalahan mitra yang disimpulkan sebagai berikut: a) Belum adanya pengetahuan mitra mengenai sosial media sebagai strategi marketing, b) Belum memahami cara membuat model social media sebagai langkah konkrit strategi pasar dan c) Belum mengetahui dan memahami e-marketing.

Mitra berkeinginan untuk mengembangkan produk dan berinovasi mengembangkan produk- produk agar lebih dapat diminati pasar. Untuk mewujudkan hal tersebut maka solusi yang ditawarkan dalam program Pengabdian kepada masyarakat ini adalah berupa penyuluhan tentang sosial media serta pemahaman tentang cara penggunaan social media sebagai strategi marketing. Tim PKM membangun sosial media marketing didalam membantu mitra untuk memasarkan hasil 
kerajinannya. Kegiatan program kemitraan masyarakat (PKM) ini adalah bertujuan untuk meningkatkan motivasi kewirausahaan mitra; meningkatkan pengetahuan dalam memberikan keterampilan dalam penggunaan media sosial untuk menunjang fungsi pemasaran produk berupa strategi pemasaran yang proaktif agar dapat meningkaatkan kemandirian hidup. Selain itu terdapat pula target luaran yang diharapkan dari kegiatan pengabdian ini adalah: a) Mitra dalam program ini dapat mengetahui sosial media sebagai strategi pemasaran, b) Mitra memahami cara pembuatan akun social media dan c) Pembuatan poster strategi pemasaran melalui social media.

\section{METODE PELAKSANAAN}

\section{A. Khalayak Sasaran}

Kegiatan pengabdian kepada masyarakat ini dilaksanakan pada tanggal 16 Juli 2020, dimana khalayak sasarannya adalah tentu saja para penyandang disabilitas yang bernaung di bawah Yayasan Bhakti Senang Hati Gianyar. Oleh karena itu untuk kelancaran kegiatan pengabdian akan berkoordinasi dengan ketua yayasan dan aparat desa setempat. Melalui penyuluhan, pelatihan dan pendampingan pemasaran online berbasis media sosial ini diharapkan wawasan dan keterampilan bagi penyandang disabilitas dapat lebih meingkat dan bermanfaat dalam memasarkan produknya.

\section{B. Metode Kegiatan}

Permasalahan bahwa bahwa belum adanya pengetahuan mitra mengenai social media sebagai strategi marketing, mitra nelum memahami cara membuat model sosial media sebagai langkah konkrit strategi pasar serta belum mengetahui dan memahami e-marketing, dapat diselesaikan dengan menggunakan metode ceramah, diskusi, sedang masalah mitra dalam penggunaan pemasaran online berbasis media sosial diselesaikan dengan memberikan pelatihan penulisan. Kegiatan ini dikemas dalam bentuk workshop.

\section{Langkah-Langkah Kegiatan}

Pelaksanaan pengabdian dilakukan dengan tiga tahapan, di mana tahap pertama merupakan tahap persiapan. Pada tahap ini Tim PKM melakukan suvei pendahuluan untuk melihat kondisi di lapangan mengenai keadaan lingkungan mitra. Dalam tahap ini dicari permasalahan-permasalahan yang dihadapi oleh mitra dalam meningkatkan penjualan di tengah pandemi covid-19. Tahap selanjutnya merupakan tahapan pelaksanaan kegiatan pengabdian. Dalam tahap ini Tim PKM melakukan kegiatan penyuluhan dan pelatihan metode pemasaran online berbasis media ssoial. Tahap yang terakhir adalah tahap evaluasi. Pada tahap ini dilakukan evaluasi atas hasil yang telah dicapai oleh peserta pelatihan. Masukan dan perbaikan lebih lanjut dapat dilakukan pada tahap ini. Evaluasi diberikan dengan mengumpulkan data yang diperoleh dari kegiatan pelatihan pemasaran online berbasis media sosial. Data diambil dengan menyimpulkan pemahaman penyandang disabilitas ketika diberikan makalah yang disampaikan dengan metode ceramah dan dilanjutkan dengan tanya jawab/diskusi. Indikator ketercapaian tujuan Pelaksanaan kegiatan Pengabdian Pada Masyarakat ini dikemas dengan menggunakan pendekatan survei dan workshop. Kegiatan dilakukan menggunakan metode ceramah, diskusi dan latihan.

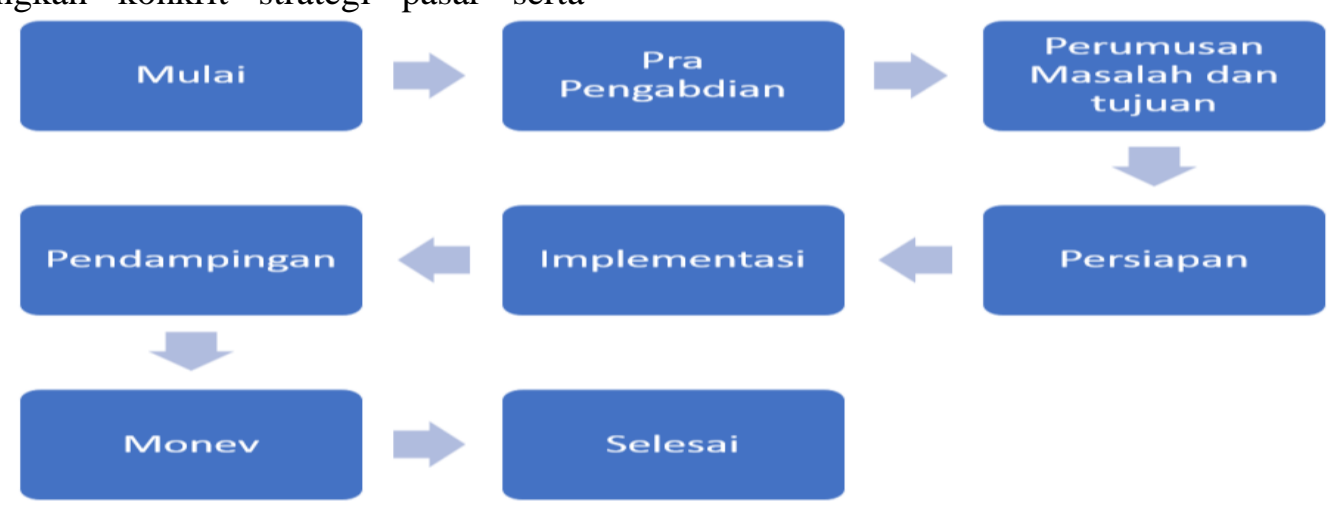

Gambar 3 Metode Pelaksanaan Pengabdian kepada Masyarakat. 


\section{HASIL DAN PEMBAHASAN}

Pelaksanaan kegiatan pengabdian ini menggunakan metode ceramah, pelatihan, pendampingan, dan diskusi. Untuk mencapai tujuan yang diharapkan, maka pelaksanaan kegiatan ini menggunakan 3 (tiga) metode, yaitu:

a. Tutorial

Tim PKM memberikan penjelasan kepada mitra berkenaan dengan materi penyuluhan tentang pentingnya sosial media sebagai strategi pemasaran, cara pembuatan akun sosial media dan pembuatan poster strategi pemasran melalui media sosial. Penyuluhan ini menggunakan alat bantu $L C D$ dan modul berbentuk manual book yang disediakan tim PKM kepada penyandang disabilitas berupa petunjuk penggunaan dari facebook marketing sehingga peserta lebih mudah dapat memahami..

Adapun langkah-langkah dalam pelaksanaan kegiatan pengabdian ini adalah sebagai berikut:

Langkah 1: Mitra diberikan materi penyuluhan tentang pentingnya sosial media sebagai strategi pemasaran.

Langkah 2: Mitra diberikan materi penyuluhan tentang pentingnya cara pembuatan akun sosial media

Langkah 3: Mitra diberikan materi penyuluhan tentang cara pembuatan poster strategi pemasaran melalui media sosial.

Langkah 4: Peserta diberikan kesempatan untuk mendiskusikan materi yang telah diberikan. Kesempatan tanya jawab diberikan untuk memperjelas hal-hal yang masih menjadi keraguan.

Langkah 5: Peserta berlatih untuk mengembangkan pemasaran media sosial

Langkah 6: Hasil survey dan pelatihan dikumpulkan dan dianalisis untuk diberikan masukan dan perbaikan lebih lanjut

\section{b. Monitoring}

Berikut adalah contoh dari halaman utama dari facebook marketing. Setiap peserta melakukan praktek berupa membuat poster usaha untuk diupload di akun Facebook masingmasing. Proses ini dilakukan untuk melihat seberapa jauh para peserta memahami dan menggunakan aplikasi yang sudah dibuat. Dengan melakukan pelatihan, pendampingan dan memberikan masukan-masukan untuk pengembangan usaha pasca pada program facebook marketing.

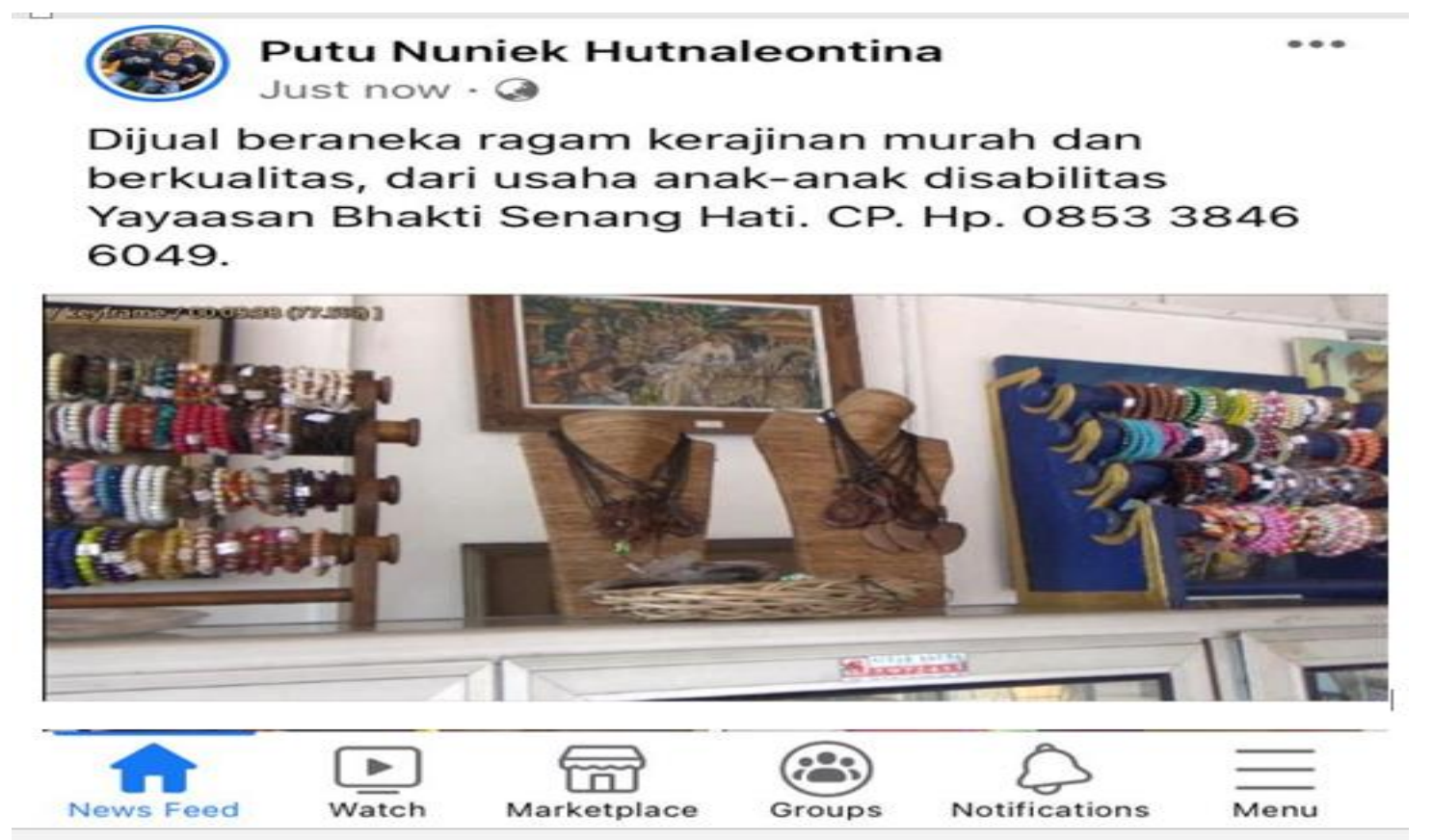

Gambar 4 Halaman Facebook Marketing 


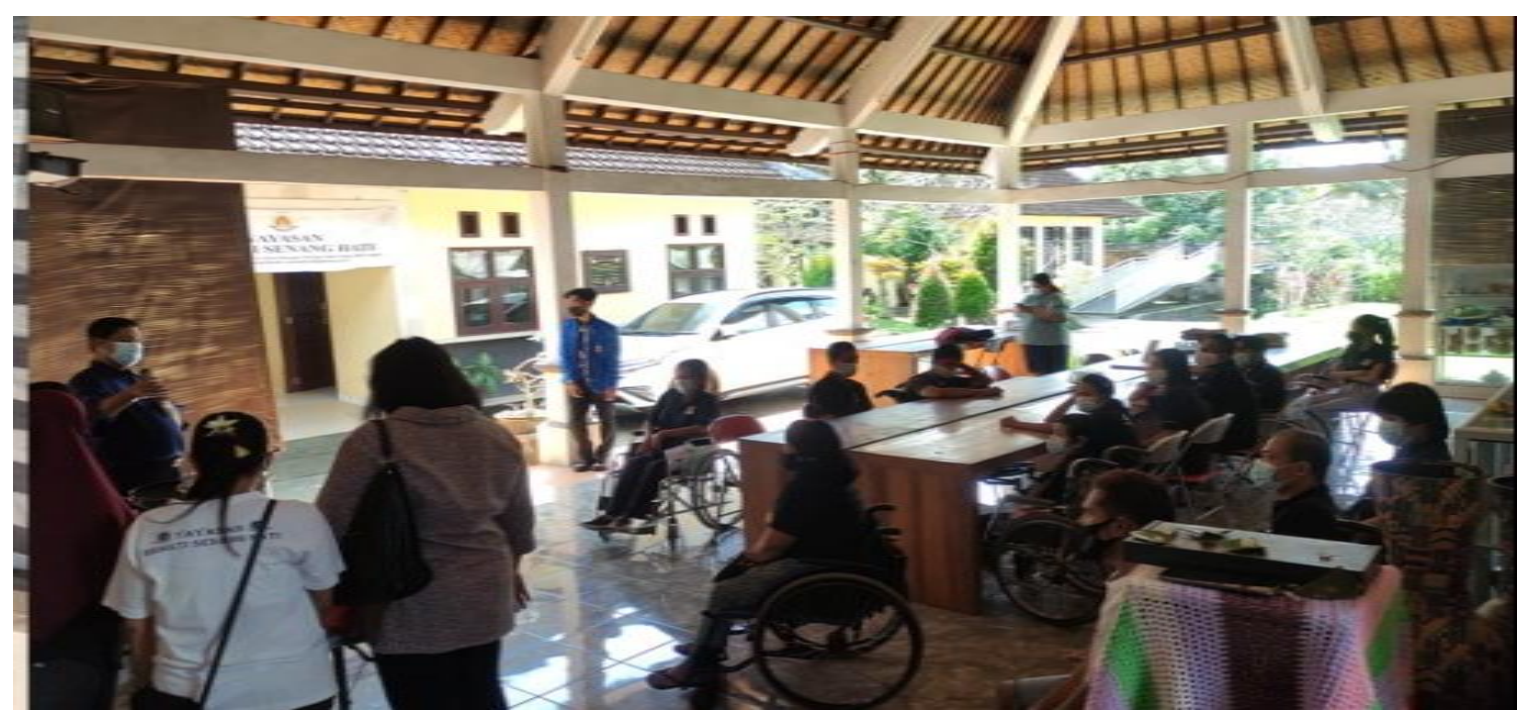

Evaluasi

Pada kegiatan evaluasi ini peserta dapat langsung bertanya kepada Tim Pengabdian Kepada Masyarakat yang mendampingi selama kegiatan berlangsung. Proses evaluasi dilakukan dengan memberikan solusi terhadap permasalahan-permasalahan mitra, maka tahapan kegiatannya disusun sebagai tabel berikut:

Tabel 1. Evaluasi Kegiatan Pengabdian Kepada Masyarakat

\begin{tabular}{llc}
\hline \multicolumn{1}{c}{ Kegiatan } & \multicolumn{1}{c}{ Luaran } & Keterangan \\
\hline $\begin{array}{l}\text { Penyuluhan pentingnya sosial } \\
\text { media sebagai strategi pemasaran }\end{array}$ & $\begin{array}{l}\text { Pemahaman mitra meningkat 40\% terkai pentingnya media } \\
\text { sosial sebagai srategi pemasaran }\end{array}$ & Tercapai \\
\hline $\begin{array}{l}\text { Penyuluhan cara pembuatan akun } \\
\text { sosial media }\end{array}$ & $\begin{array}{l}\text { Mitra bisa membuat akun media sosial di Handphone } \\
\text { masing-masing }\end{array}$ & Tercapai \\
\hline Penyuluhan Poster Promosi & Mitra bisa membuat poster promosi usaha. & Tercapai \\
\hline Upload poster di media social & Mitra bisa mengupload poster usaha di media sosial & Tercapai \\
\hline
\end{tabular}

\section{SIMPULAN DAN SARAN}

Berdasarkan hasil pengabdian kepada masyarakat dalam bentuk penyuluhan dan pelatihan praktek pemasaran onlinne berbasis media sosial bagi mitra dalam hal ini usaha kerajinan bagi penyandang disabilitas dibawah naungan Yayasan Bhakti Senang Hati Gianyar, maka simpulan yang dapat digambarkan adalah bahwa kegiatan penyuluhan penggunaan social media sebagai inovasi dan strategi pemasaran dapat diterima dan dipahami oleh mitra, yang selanjutnya dapat menciptakan peluang bisnis bagi mitra dalam hal memasarkan produk kerajinannya, selanjutnya peningkatan pemasaran dan pada akirnya pendapatan akan semakin tinggi.

Adapun saran dari kegiatan ini adalah untu mitra disarankan untuk membandingkan berbagai bentuk aplikasi media sosial yang terpercaya dalam arti mudah dalam penggunaannya, mempunyai kebermanfaatan, mempunyai kredibiitas tinggi dan terdapat informasi yang lengkap.

\section{UCAPAN TERIMAKASIH}

Tim Pelaksana mengucapkan terima kasih kepada Rektor Universitas Warmadewa Denpasar, Ketua Lembaga Pengabdian Masyarakat Universitas Warmadewa atas dukungan pendanaan kegiatan melalui program Hibah Institusi Internal Program Pengabdian Kepada Masyarakat dengan Program kemitraan dengan Yayasan Bhakti Senang Hati Desa Siangan,Gianyar-Bali.

\section{DAFTAR PUSTAKA}

Achmad, Z. A. (2020). Pemanfaatan media sosial dalam pemasaran produk UMKM di Kelurahan Sidokumpul, Kabupaten Gresik. Jurnal Ilmu Komunikasi, 10(1), 1731. 
Hidayati, D. A., \& Ningsih, P. L. (2017). Pemberdayaan Masyarakat Melalui Kegiatan Wirausaha Berbasis Keahlian Dan Teknologi (Studi Pada Mahasiswa Fisip Universitas Lampung). Sosiologi: Jurnal Ilmiah Kajian Ilmu Sosial dan Budaya, 19(1), 23-30.

Pramuki, N. M. W Arie \& Cita Ayu, P. (2020). Antecedents of the Use of MSME Social Media:In The Perspective of Technology Acceptance Model Theory. International Journal of Contemporary Research and Review, 11(04), 21776-21786. https://doi.org/10.15520/ijcrr.v11i04.800
Raden Suci, R. (2020). Implementasi Peraturan Walikota Yogyakarta Nomor 16 Tahun 2017 Tentang Komite Perlindungan Dan Pemenuhan Hak-Hak Penyandang Disabilitas Di Kecamatan Wirobrajan (Doctoral dissertation, STPMD" APMD").

Yulius, M. (2020). Hak Penyandang Disabilitas Di Bidang Politik Menurut Undang-Undang Nomor 8 Tahun 2016 Tentang Penyandang Disabilitas. Lex Administratum, 8(3). 